\title{
Brug af portfolioopgaver og peer feedback for at øge sammenhæng og studenterinddragelse i undervisningen - et praksiseksempel
}

Lisa Gregersen Østergaard, adjunkt, Institut for Folkesundhed, Aarhus Universitet og Fysio- og Ergoterapiafdelingen, Aarhus Universitetshospital

Thomas Maribo, lektor, Institut for Folkesundhed, Aarhus Universitet og DEFACTUM Region Midtjylland

Janne Saltoft Hansen, E-læringskonsulent, Center for Sundhedsvidenskabelige Uddannelser (CESU), Aarhus Universitet

\section{Faglig artikel, fagfællebedømt}

Formålet er at beskrive, hvordan portfolioopgaver og peer feedback kan øge sammenhængen og studenterinddragelse i et kursusforløb.

De studerende opnår indstillingsbetingelse til eksamen på deres semesterkursus ved godkendelse af mindst tre af fem portfolioopgaver. Der er tre individuelle opgaver med peer feedback og to gruppeopgaver.

I evalueringen af forløbet blev der anvendt elektroniske kursusevalueringer af alle studerende, semistruktureret interview med én studerende og mundtlige evalueringer med hhv. studerende og undervisere.

Vores resultater indikerer, at brug af portfolioopgaver og peer feedback har øget sammenhængen i kursusforløbet og sikret, at de studerende arbejder med det faglige stof mellem undervisningsgangene. Det har bidraget til at fremme brugen af dybdelæringsstrategi og øget refleksion. Vi vurderer, at kriteriebaserede feedbackvejledninger og rubrics har højnet de studerendes tryghed og øget kvaliteten af deres opgavebesvarelser. Vi anser det som nødvendigt for gennemførelse af peer feedback, at de komplicerede processer ved peer feedback understøttes af et stabilt og velfungerende digitalt peer feedback-værktøj.

\section{Indledning}

Som undervisere $\varnothing$ nsker vi at skabe et læringsmiljø, der understøtter læring hos vores studerende, hvor der er sammenhæng mellem målbeskrivelse, undervisningsformer, bedømmelseskriterier og eksamensformer, og hvor de studerende involveres aktivt som medskabere af undervisningen.

Samtidig mødes vi af evalueringer som den nye studiemiljøunders $\varnothing$ gelse fra Aarhus Universitet (AU), hvor det fremgår, at ca. halvdelen af de studerende ved Health i 2017 efterlyser mere feedback på, hvad der kendetegner en god opgaveløsning. Herunder om den studerende lærer det, der kræves, og hvordan den respons, der gives, kan bruges videre frem. Tendenser, der går på tværs af fakulteter og institutioner for videregående uddannelser.

På kurset Tværfaglig og Tværsektoriel Rehabilitering ved Den Sundhedsfaglige Kandidatuddannelse på AU har disse $\emptyset$ nsker og krav ført til brug af portfolioopgaver som et centralt element i 
undervisningsformen, og de studerende skal som indstillingsbetingelse til eksamen have godkendt en portfolio. Portfolioopgaverne er udviklet som et led i førsteforfatterens adjunktpædagogikum og i samarbejde med de øvrige medforfattere.

Formålet med denne artikel er at beskrive, hvordan brug af portfolioopgaver og peer-feedback kan skabe sammenhæng i et undervisningsforløb, sikre, at de studerende arbejder med det faglige stof mellem undervisningsgangene, og gøre de studerende til medskabere af undervisningen. Artiklen beskriver de pædagogiske principper, den praktiske udførelse og evaluering af forløbet. Derudover diskuteres både de praktiske erfaringer og de pædagogiske principper.

\section{Beskrivelse af konteksten}

Tværfaglig og Tværsektoriel Rehabilitering er et obligatorisk kursus på 2. semester på Rehabiliteringslinjen ved Den Sundhedsfaglige Kandidatuddannelse, AU. Undervisningsformen er forelæsning, holdundervisning og løsning af portfolioopgaver. Kurset består af 17 undervisningsgange á 4 lektioner og afsluttes med en 4 timers skriftlig eksamen. Der er ca. 25 studerende på holdet.

Rehabiliteringslinjen er en forholdsvis nyoprettet linje, hvor første hold studerende startede i foråret 2016. Som indstillingsbetingelse til eksamen på kurset Tværfaglig og Tværsektoriel Rehabilitering skal de studerende have godkendt en portfolio. Underviserne har valgt, at denne portfolio består af fem portfolioopgaver, hvoraf de studerende skal bestå mindst tre opgaver for at blive indstillet til eksamen. Vi definerer portfolioopgaver som en samling af opgaver, der giver struktur for en dokumentation af den studerendes indsats og fremskridt (Smith \& Tillema, 2010). Smith og Tillema (2010) beskriver fire forskellige portfoliotyper, og i denne artikel benyttes en kombination af $\varnothing$ velsesportfolio og reflektiv portfolio. De studerende skal bestå mindst tre ud af fem portfolioopgaver, men opfordres til at aflevere alle fem opgaver. Der er således en kombination af obligatoriske og frivillige opgaver, og alle portfolioopgaver er udformet med stigende sværhedsgrad (Smith \& Tillema, 2010). Indholdet i de fem portfolioopgaver er knyttet til det faglige stof, som de studerende præsenteres for til holdundervisningen. Alle portfolioopgaver udleveres og afleveres via læringsplatformen Blackboard Learn (Bb). Der er tre individuelle opgaver og to gruppeopgaver. En af portfolioopgaverne afleveres som en kort video, en anden opgave afsluttes med et gruppeoplæg, og ved tre af portfolioopgaverne anvendes der peer feedback. Ved løsning af gruppeopgaver kan de studerende via $\mathrm{Bb}$ anvende fildeling, diskussionsforum, wiki m.m. De studerende får individuel besked via Bb, om de har bestået de enkelte portfolioopgaver. Der er gennemført to undervisningsforløb (forår 2016 og forår 2017), hvor portfolioopgaver er anvendt som indstillingsbetingelse til eksamen.

\section{Bærende pædagogiske principper}

Det har været vigtigt i udvikling af undervisningen, at de bærende pædagogiske principper understøtter sammenhæng og alignment både mellem undervisning og eksamen og løbende gennem undervisningsforløbet. Samtidig har der været lagt vægt på aktiverende undervisning og at gøre de studerende til medskabere i undervisningsforløbet. De bærende pædagogiske principper er derfor constructive alignment, formativ feedback og peer feedback. 


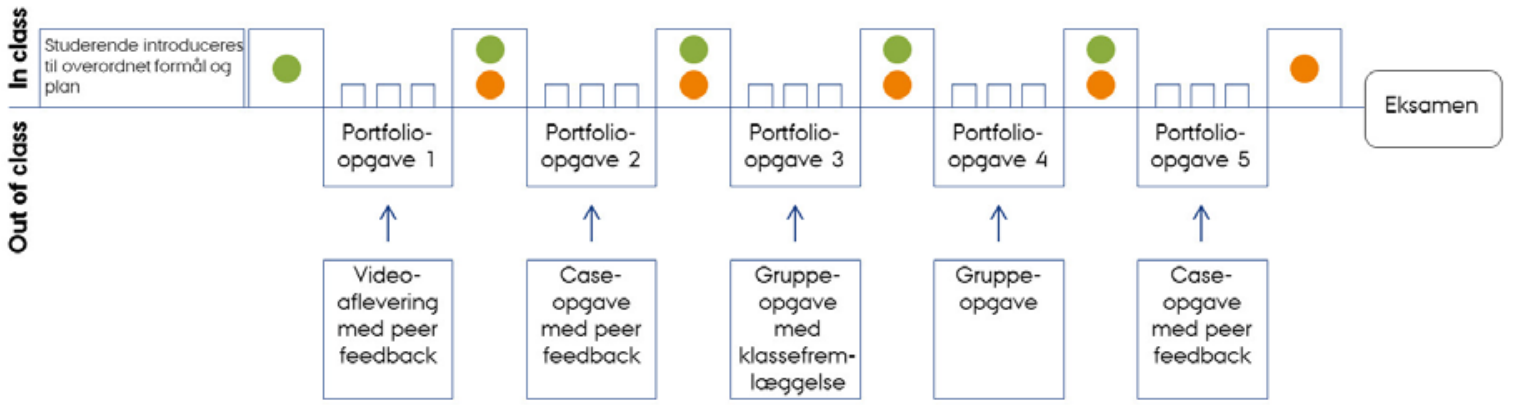

Figur 1: Opbygning af portfolioopgaverne: Figuren viser portfolioopgavernes placering out of class og introduktion og opsamling in class. Der foregår andre aktiviteter $i$ kurset både in og out of class, men disse er ikke medtaget.

\section{Constructive alignment}

Et centralt begreb for at skabe større læring hos studerende er constructive alignment, som er den type undervisning, der er kendetegnet ved, at der er sammenhæng mellem målbeskrivelse, undervisningsformer, bed ømmelseskriterier og eksamensformer (Biggs \& Tang, 2011).

Det har under udvikling af kurset været en udfordring, at de studerende skulle modtage holdundervisning med vægt på gruppearbejde og holddiskussioner, mens eksamen er en fire timers skriftlig stedprøve. Det har ikke været muligt at ændre eksamensform på grund af et krav om samme eksamensform som på uddannelsens sideløbende linje.

Der er i kurset derfor udviklet portfolioopgaver, der kan bidrage til at skabe sammenhæng mellem kursets læringsmål, de studerendes undervisning, deres forståelse af stoffet og deres præstation ved eksamen. For at skabe en sammenhæng mellem den undervisning, de studerende modtager, og eksamensformen er de skriftlige portfolioopgaver tænkt som en måde, hvorpå de studerende kan øve formidling af deres viden fra litteraturen og holdundervisningen og på skrift demonstrere opnåelse af kursets læringsmål.

\section{Formativ feedback}

På kurset Tværfaglig og Tværsektoriel Rehabilitering betyder brugen af portfolioopgaver i undervisningen, at feedback primært gives som formativ feedback løbende gennem undervisningsforløbet. Portfolioopgaverne er, som det ses af figur 1, opbygget således, at de fem portfolioopgaver er spredt ud over semestret. Selv om de studerende blot skal have godkendt tre portfolioopgaver for at blive indstillet til eksamen, opfordres de til at løse alle fem, uanset om de tre første er bestået. Opgaverne løses out of class, men in class er der i selve undervisningen sat tid af til at introducere portfolioopgaverne og samle op på resultaterne, hvilket er illustreret med grønt og orange i figur 1. Via feedback undervejs i et undervisningsforløb, også kaldet formative feedback (Biggs \& Tang, 2011), kan de studerende bruge og arbejde med den feedback, de får, mens de stadig har adgang til at kunne stille spørgsmål til underviseren. Derved bliver der i langt højere grad mulighed for, at feedbacken kan bruges som feed forward (Hattie, 2007), da den kan pege fremad, og den studerende kan udnytte og afklare, hvad det næste skridt er, og hvilke forbedringer der er nødvendige. Samtidig er feedback, der gives i løbet af undervisningen, med til at moti- 
vere og understøtte dybdelæringsstrategier og de selvregulerende læreprocesser (Wood, 2010). Formativ feedback bliver derfor en integreret del af læreprocesserne.

Det formative aspekt i portfolioopgaverne kan give den studerende en $\emptyset$ get mulighed for at få repeteret stoffet i tæt tilknytning til undervisningen, hvilket kan højne den studerendes udbytte af den viden, som bliver præsenteret (Biggs \& Tang, 2011). Portfolioopgaverne er tilrettelagt, så de omhandler nogle af fagets helt centrale emner. De studerende præsenteres for disse emner gennem den obligatoriske litteratur og i holdundervisningen, og i dagene efter denne undervisning $\emptyset \emptyset$ ser de studerende den tilhørende portfolioopgave. Herved får de studerende via portfolioopgaverne repeteret det faglige stof med mulighed for en større lagring af den nye viden.

Foruden feedback til studerende giver formativ feedback også underviserne viden omkring de studerendes niveau og udfordringer undervejs gennem undervisningen. Dette kan bruges til $\emptyset$ bende at justere aktiviteterne i undervisningen, så de matcher den aktuelle gruppe af studerende. Herved bliver portfolioopgaver en out of class-aktivitet, der kan understøtte Just in Time Teaching (Novak et al., 1999) og give mulighed for mere interaktive og varierede undervisningsmetoder (Wood, 2010).

\section{Peer feedback}

Tre af portfolioopgaverne er udformet som peer feedback. Den feedback, som de studerende modtager i disse opgaver, er derfor givet af medstuderende. Som beskrevet af Biggs og Tang (Biggs \& Tang, 2011) er det, den studerende lærer, et resultat af, hvad den studerende gør, dvs. af læringsaktiviteterne. Forskning peger på, at de studerendes læringsudbytte afhænger af kvantiteten af deres arbejdsindsats og kvaliteten af deres læringsstrategier (Herrmann \& BagerElsborg, 2014). Læringsudbyttet bliver bedre, hvor der anvendes dybdelæringsstrategier, end hvor de anvendte strategier fører til overfladelæring. Med dybdelæringsstrategier forstås her tilgange til læring, der er fyldestgørende for at opnå det tilsigtede læringsudbytte på det tilsigtede taksonomiske niveau (Biggs \& Tang, 2011). I opgaverne med peer feedback skal de studerende ud over at skrive en opgave give feedback til en anden studerende på dennes opgave. Herved tvinges den studerende i høj grad til at anvende dybdelæringsstrategier, da det at give feedback på en andens opgave og argumentere skriftligt stiller store krav til den studerendes forståelse af stoffet. Den studerende skal ikke blot fokusere på sin egen forståelse, men tydeliggøre denne forståelse for en medstuderende i relation til dennes opgavebesvarelse.

Samtidig med at læringsprocessen styrkes, forventes det også, at review af medstuderendes arbejde betyder $\emptyset$ get feedback til den studerendes eget arbejde. Review af en medstuderendes opgave kan udløse selvreguleringsprocesser hos den studerende (Nicol \& Macfarlane-Dick, 2006), da den studerende sammenligner sin egen netop afleverede opgave med den opgave, som evalueres (Nicol et al., 2014). Herved genereres indre (internal) feedback til den studerende. I portfolioopgaverne evaluerer de studerende den samme opgave, som de selv har afleveret, og kan derfor sammenholde deres egen besvarelse med en medstuderendes. Det vil sige, at den studerende gennem evalueringer af en medstuderendes opgave kan opnå en større forståelse for, at der ved komplekse problemstillinger kan være flere mulige måder, en opgave kan løses på. Det kan give den studerende en inspiration til løsning af fremtidige opgaver. I det hele taget kan der være stor læring forbundet med at give medstuderende feedback, da det kræver en større forståelse af stoffet ikke blot at løse en opgave, men også at vurdere andres fortolkninger og svar (Nicol, 2010). Den indre feedback spiller sammen med den ydre (external) feedback, som 
fås gennem medstuderendes review af ens eget arbejde. I komplicerede indre feedbackprocesser kan indre og ydre feedback interagere og sammenholdes med nuværende indre mål, som ikke nødvendigvis behøver at være sammenfaldende med de mål, som underviseren har sat for opgaven. Denne sammenligning kan føre til utallige ændringer på både kognitivt, motivationseller adfærdsniveau (Nicol \& Macfarlane-Dick, 2006), som f.eks. nyfortolkning af opgave, regulering af emneforståelse, regulering af egne mål eller læringsstrategier. Indre feedback opnået gennem review kan derfor blive til i en aktiv og selvregulerende læreproces i modsætning til den ydre feedback, der i højere grad opstår i en fortælleproces. Når studerende i opgaver med peer feedback, som i de nævnte portfolioopgaver, giver og modtager feedback på samme opgave kan de to feedbacktyper supplere hinanden (Nicol et al., 2014).

Derfor kan anvendelsen af peer feedback underst $\varnothing$ tte kritisk tænkning, aktiv tolkning og refleksion, og den studerende kan derigennem tage kontrol over egen læring og gennem sit review generere feedback og kritik også på eget arbejde (Nicol et al., 2014). Peer feedback kan hermed ses som en mulighed for at $\emptyset$ ge både kvalitet og kvantitet af feedback til den enkelte studerende.

De studerendes evaluering sammenholdes senere i artiklens diskussion med de forventninger, vi har til, at brug af portfolioopgaver kan underst $\varnothing$ tte de pædagogiske principper, samt hvilke forventninger der i praksis indfries i dette kursus.

\section{Opbygning af portfolioopgaverne}

I det følgende beskrives de fem portfolioopgaver. Alle opgaveformuleringer er udarbejdet af underviserne med udgangspunkt i fem af kursets centrale faglige emner. Ved en af opgaverne er de studerende blevet inddraget $\mathrm{i}$ at udarbejde en feedbackvejledning, mens feedbackvejledninger for de фvrige opgaver er blevet udarbejdet af underviserne. Opgaverne er formuleret som åbne spørgsmål og med en angivelse af forventet omfang. In class på kursets 2 . undervisningsgang får de studerende en introduktion til det overordnede formål med portfolioopgaverne samt en overordnet plan, som inkluderer opgaveemner, typer af opgaver, datoer for frigivelse af opgaverne, afleveringsfrister, godkendelsesprocedurer og tidspunkter. Da de studerede primært løser opgaverne mellem holdtimerne, har underviserne valgt at benytte feedbackvejledninger og rubrics, som er et matrix til kriteriebaseret feedback, til klart at beskrive, hvad der forventes for at løse opgaverne.

Portfolioopgave 1 er en individuelt løst opgave, som består af opgave 1A og 1B. I opgave 1A afleverer de studerende en video, hvor de på 2-3 minutter redegør for spørgsmålet: Hvad er rehabilitering? I opgave 1B giver de studerende peer feedback på en medstuderendes video. Denne peer feedback gives skriftligt med udgangspunkt i en feedbackvejledning.

Portfolioopgave 2 er en individuelt løst opgave, der består af opgave 2A og opgave 2B. I opgave $2 \mathrm{~A}$ afleverer de studerende en skriftlig vurdering af funktionsevne ud fra en case. I opgave $2 \mathrm{~B}$ giver de studerende peer feedback på en medstuderendes opgave ud fra bestemte kriterier og en overordnet vurdering af opgaven ud fra en rubric. Se eksempel på kriterier og rubric i figur 2. Forud for løsning af portfolioopgave 2 modtager de studerende holdundervisning om det teoretiske stof, som opgaven bygger på. De studerende bliver bedømt på deres peer feedback. Hvis underviseren vurderer, at det er nødvendigt at korrigere den feedback, en studerende har modtaget af en medstuderende, gøres dette via Bb. Foruden de individuelle tilbagemeldinger på Bb 
er der en halv lektion med en overordnet tilbagemelding til holdet om, hvad der var godt, og hvad der generelt kan arbejdes mere med.

\section{Udvalgt kriterie fra feedbackvejledningen for opgave 2B.}

Har den studerende beskrevet funktionsevnen tilfredsstillende med inddragelse af de fem komponenter (krop, aktivitet, deltagelse, omgivelsesmæssige faktorer og personlige faktorer)?

Eksempel på underspørgsmål for området krop:

Er der en dækkende beskrivelse af personens begrænsninger på komponenten krop?

Sæt ét kryds:

- Ja, fuldt dækkende

- Ja, delvist dækkende

- $\quad$ Nej

o Hvis delvist dækkende eller nej, skriv hvad der mangler at blive belyst?

Figur 2a: Eksempel på feedbackvejledning i opgave $2 B$

\begin{tabular}{|l|c|l|}
\hline Sæt X & Niveau & Krav for at niveauet er opfyldt \\
\hline & 0 & $\begin{array}{l}\text { Mindre end fem komponenter er beskrevet. } \\
\text { Beskrivelse af komponenterne er ufuldstændig eller med store mangler. }\end{array}$ \\
\hline 1 & $\begin{array}{l}\text { Alle fem komponenter er beskrevet acceptabelt i besvarelsen. } \\
\text { Der er ingen overvejelser beskrevet om interaktion mellem komponenter- } \\
\text { ne. }\end{array}$ \\
\hline 2 & $\begin{array}{l}\text { Alle fem komponenter er beskrevet acceptabelt i besvarelsen. } \\
\text { Interaktion mellem nogle af komponenterne er beskrevet. }\end{array}$ \\
\hline 3 & $\begin{array}{l}\text { Alle fem komponenter er beskrevet indgående i besvarelsen. } \\
\text { Interaktion mellem komponenterne er beskrevet for alle fem komponen- } \\
\text { ter. }\end{array}$ \\
\hline
\end{tabular}

Figur 2b: Rubric til overordnet vurdering af portfolioopgave $2 B$

Portfolioopgave 3 er en gruppeopgave med fælles aflevering på $\mathrm{Bb}$ og en gruppefremlæggelse. Emnet for opgaven er udvikling af komplekse interventioner i rehabilitering, hvor de studerende på baggrund af en udleveret protokolartikel skal udarbejde en generel logisk model for den intervention, der er beskrevet i artiklen. Forud for opgaven er de studerende via holdundervisning blevet præsenteret for det faglige stof, der knytter sig til emnet. Der er en kort introduktion til opgaven, og de studerende får efterfølgende mulighed for at arbejde med opgaven i tilfældigt sammensatte grupper i en enkelt lektion, hvor underviseren er til stede, og der er mulighed for at spørge om hjælp. De studerende inddrages i udvikling af bedømmelseskriterier ved at drøfte i grupper på 2-3 studerende, hvilke kriterier de mener er vigtige at vurdere denne opgave ud fra. 
Forslag skrives ind i en Padlet (https://padlet.com). Med udgangspunkt i den fælles Padlet vælges der, ud fra en drøftelse på holdet, 3 bedømmelseskriterier, der danner grundlag for underviserens bedømmelse af portfolioopgave 3 .

Portfolioopgave 4 er en gruppeopgave med skriftlig aflevering. Opgaven omhandler evaluering af et rehabiliteringsforløb med brug af fagligt stof fra flere undervisningsemner, blandt andet undervisning om designs, måleredskaber og mål for rehabilitering. Tilbagemelding til de enkelte grupper sker via Bb samt ved en samlet overordnet skriftlig feedback til de studerende.

Portfolioopgave 5 er en individuelt løst opgave med peer feedback svarede til portfolioopgave 2. Portfolioopgave 5 er en videreudbygning af portfolioopgave 2, idet den er baseret på en ny case med $\varnothing$ get kompleksitet. Foruden den opgave, der er stillet i 2A, er der i opgave 5A en ekstra opgave, hvor de studerende skal opstille rehabiliteringsmål ud fra bestemte kriterier. De studerende er præsenteret for kriterierne i undervisningen og bliver bed ømt på deres peer feedback.

\section{Metode}

I evaluering af forløbet har vi anvendt skriftlig kursusevaluering udsendt til alle studerende på kurset, semistruktureret interview af én studerende og mundtlig evaluering med alle studerende på kurset samt undervisere.

Den skriftlige kursusevaluering, vi har anvendt, er den obligatoriske kursusevaluering ved AU. Herfra anvendes det obligatoriske spørgsmål, hvor de studerende vurderer deres muligheder for tilbagemelding/vejledning vedrørende deres faglige præstationer. Desuden er der i den skriftlige kursusevaluering blevet indsat tre ekstra spørgsmål som supplement til de obligatoriske og med lignende formuleringer. I disse spørgsmål er spurgt direkte til de studerendes udbytte af portfolioopgaverne. Ordlyden af det første spørgsmål er: Jeg vurderer udbyttet af portfolioopgaverne som? Svarmulighederne er fastlagt i den obligatoriske kursusevaluering og omfatter følgende svarmuligheder: meget stort udbytte, stort udbytte, noget udbytte, lille udbytte eller intet udbytte.

Derudover er de studerende i to efterfølgende spørgsmål blevet bedt om at skrive op til tre ting, som fungerede godt i portfolioopgaverne, og op til tre ting, som de oplevede fungerede mindre godt i portfolioopgaverne. Som følge af anonyme evalueringer kan udsagnene ikke bruges direkte, og der er foretaget en tematisk analyse, hvor hvert enkelt udsagn er kategoriset (Braun \& Clarke, 2006). Kategorierne er lavet med udgangspunkt i de konkrete udsagn, og herefter er de overordnede temaer fundet.

Vi har gennemført et semistruktureret interview med en studerende for at få et mere nuanceret indblik i en studerendes erfaring med portfolioopgaverne. Den studerende meldte sig frivilligt, efter at underviseren åbent havde søgt en interviewperson på Bb. Interviewet havde en varighed på 20 minutter og blev efterfølgende transskriberet.

Der er afholdt et evalueringsmøde i 2016 og et evalueringsmøde i 2017 mellem underviserne og den tilknyttede e-læringskonsulent for at indsamle erfaringer med henblik på at optimere forløbet. Endelig er der afholdt en mundtlig evaluering af kurset som helhed med de studerende $\mathrm{i}$ både 2016 og 2017. 


\section{Evalueringen}

Her følger relevante resultater af de enkelte evalueringer. I alt har 20 ud af 23 studerende besvaret kursusevalueringen for kurset Tværfaglig og Tværsektoriel Rehabilitering efter forløbet $\mathrm{i}$ 2017. $70 \%$ af de studerende har vurderet deres udbytte af portfolioopgaverne som værende stort udbytte eller meget stort udbytte (figur 3). Ud af de 20 studerende er portfolioopgaverne nævnt af 10 studerende i fritekstfeltet, hvori de har kunnet beskrive, hvad de synes har været godt ved kurset.

\section{Jeg vurderer mit udbytte af} portfolioopgaverne som

Meget stort udbytte Stort udbytte Noget udbytte Lille udbytte Intet udbytte Undlod af svare

Figur 3: Spørgsmål fra kursusevaluering 2017 vedr. udbytte af portfolioopgaverne

Hele $85 \%$ af de studerende er enige eller delvist enige i, at der i undervisningsforløbet har været gode muligheder for at få tilbagemeldinger/vejledning vedrørende faglige præstationer (figur 4).

\section{Der har i undervisningsforløbet været gode muligheder for at få \\ $60 \%$ \\ $25 \%$ tilbagemelding/vejledning vedrørende mine faglige præstationer \\ Enig Delvist enig Hverken eller Delvist uenig Uenig Undlod af svare}

Figur 4: Spørgsmål fra kursusevaluering 2017 vedr. tilbagemeldinger på faglige præstationer

Desuden har de studerende i fritekst beskrevet tre ting, som de synes henholdsvis fungerede godt og mindre godt. Af hensyn til anonymiteten er udsagnene ikke brugt direkte, men kategoriserede. Kategorierne ses i figur 5 og 6. 


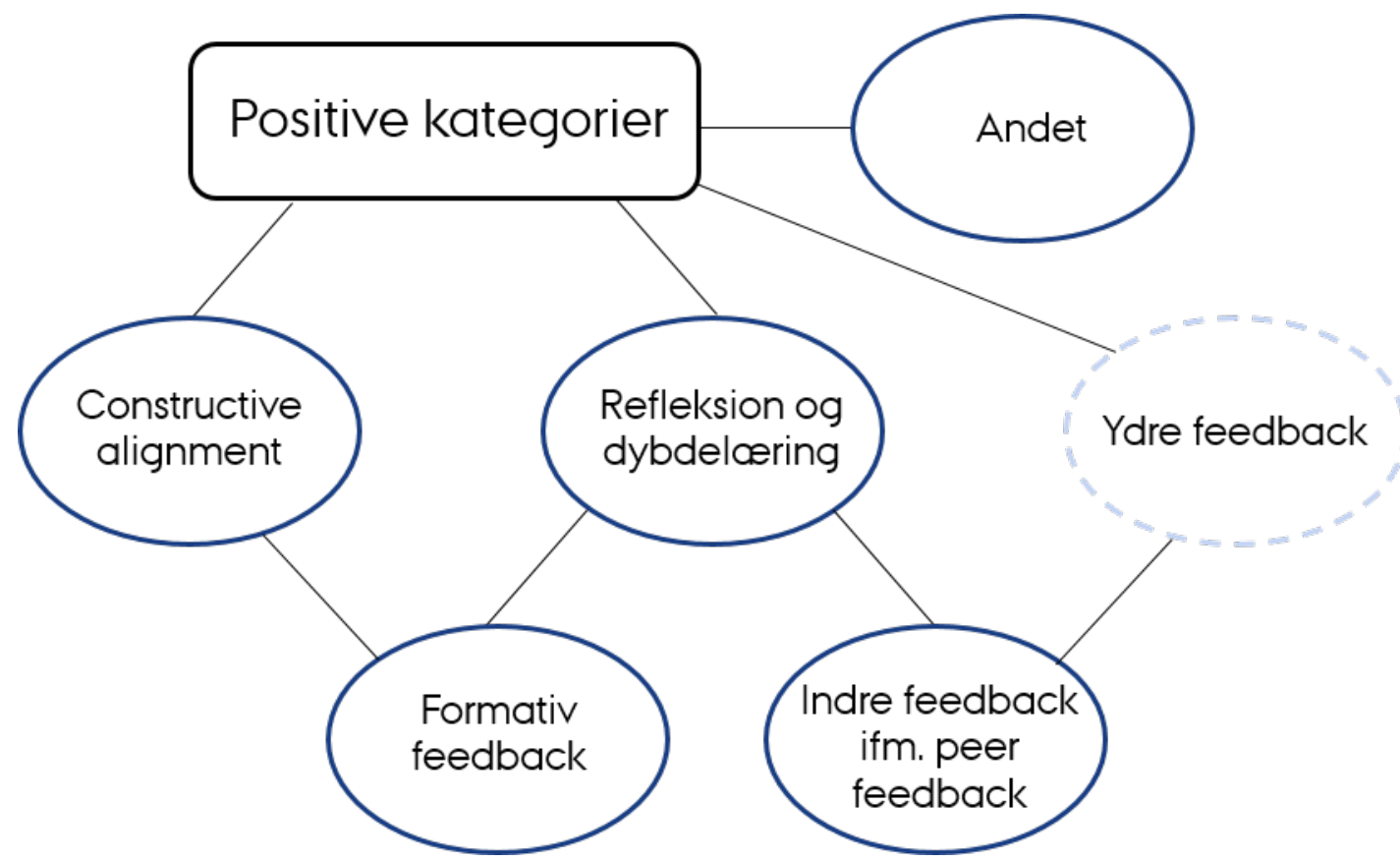

Figur 5: Kategoriserede positive udsagn fra kursusevaluering 2017

Det sorte rektangel repræsenterer vores fortolkning af en samlende overskrift.

Mørkeblå ellipser repræsenterer kategorier med mere end 5 udsagn.

Den stiplede ellipse repræsenterer en forventet kategori, men ingen positive udsagn fra evalueringen kunne kategoriseres her.

Streger binder kategorier sammen, hvor flere af de studerende i udsagnene beskriver en forbindelse.

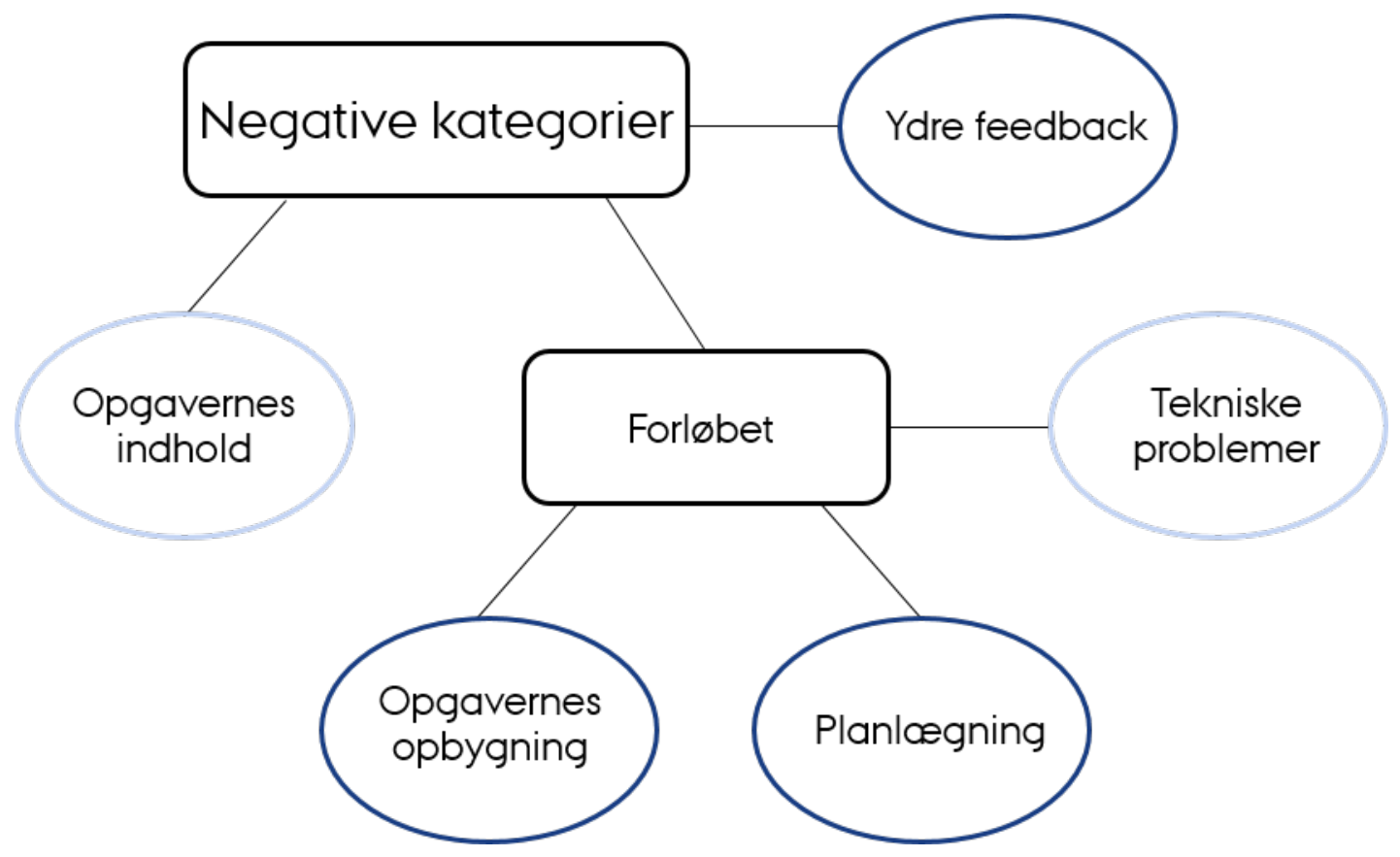

Figur 6: Kategoriserede negative udsagn fra kursusevaluering 20

Det sorte rektangel repræsenterer vores fortolkning af en samlende overskrift.

Mørkeblå ellipser repræsenterer kategorier med mere end 5 udsagn.

Lyseblå ellipser repræsenterer kategorier med mindre end 5 udsagn. 
Langt de fleste udsagn omkring ting, der fungerede godt (positive kategorier), vedrører et af de pædagogiske principper, men nogle få under kategorien 'Andet' har at gøre med bl.a. opgavernes opbygning og skrivetræning. Af udsagn omkring ting, der fungerer mindre godt, vedrører kun 'Ydre feedback' de pædagogiske principper, mens de øvrige udsagn primært har at gøre med aktivitetens forløb: Hvordan var opgaverne opbygget, hvordan var planlægningen i forhold til resten af semestret, og hvilke tekniske udfordringer opstod? Udsagnene kan derfor tematiseres i forhold til, om de omhandler forløbet eller de pædagogiske principper. Disse to temaer gennemgås nærmere i diskussionen.

Foruden kursusevalueringen er der foretaget en opgørelse over, hvor mange studerende der har afleveret portfolioopgaverne 4 og 5 , selv om de har bestået de tre første portfolioopgaver. Både i 2016 og i 2017 har alle studerende afleveret de tre første portfolioopgaver, mens én studerende ikke har afleveret portfolioopgave 4 og nogle få ikke har afleveret portfolioopgave 5. I 2017 har nogle misforståelser dog betydet, at flere først har gennemført portfolioopgave $5 \mathrm{i}$ forbindelse med eksamen ${ }^{1}$.

I interviewet med den studerende er spurgt til den studerendes erfaringer med de fem portfolioopgaver. I det følgende ses et uddrag af den studerendes svar:

"... de var skidegode ... jeg synes virkelig, det var en god ide at lave portfolioopgaver helt kanon ... jeg synes virkelig, jeg har fået sat på plads, hvad handler det her egentlig om? F.eks. i forhold til den første case i portfolioopgave 2, ... jeg har ikke vidst noget om ICF ..., så det var sjovt at se det og prøve noget nyt ..., og vi fik faktisk lov at prøve det to gange, så det var supergodt at bygge det op, og til eksamen, der vidste jeg, hvad det er, det handler om ... Der skulle jeg ikke bruge tid på at finde ud af, hvordan man gør."

Interviewer: Hvordan var det at lave det, vi kalder peer feedback, altså hvor du evaluerede dine medstuderendes opgaver, og de evaluerede din?

Studerende: "Det var hamrende fedt for mig, fordi at vedkommende, der havde lavet de opgaver, jeg skulle rette, var sindssygt dygtig, så der fik jeg jo nogle gode tips til, hvordan jeg kan lave min opgave en anden gang. Jeg synes begge gange, at jeg fik en opgave at rette, som var rigtig god, hvor jeg tænkte, at det skulle jeg måske også have brugt ... og vedkommende, der rettede min opgave, var heller ikke en, som bare skrev: 'Hvor er det flot'... men der var også noget kød på, hvor vedkommende skrev, at jeg kunne måske også have gjort det eller det ... på en venlig måde, men alligevel hvor jeg godt kunne se, at det har du fuldstændig ret i. Så jeg synes, det var svært, men også rigtig godt. Og man skylder jo også at give en god feedback til den, der har lavet et stykke arbejde."

I diskussionen inddrages og diskuteres resultaterne fra de forskellige evalueringer.

${ }^{1}$ I detaljer fordeler aflevering af portfolioopgave 5 sig således: Tre studerende har fravalgt at aflevere portfolioopgave 5 i 2016. På kurset i foråret 2017 har 10 studerende ikke afleveret portfolioopgave 5. I den mundtlige evaluering er det efterfølgende kommet frem, at dette primært skyldes manglende opmærksomhed på, at deadline var sammenfaldende med en stor opgave i et andet fag. Efterfølgende har yderligere 5 af de studerende gennemført opgaven som forberedelse til deres eksamen. 


\section{Diskussion af metode}

Efter første gennemførelse af forløbet i 2016 foretog vi et semistruktureret interview med en studerende med henblik på at indsamle viden om de studerendes erfaringer med portfolioopgaverne. Det semistrukturerede interview er en egnet metode til at indsamle subjektive oplevelser, men kan grundet det begrænsede materiale (én studerende) kun tillægges mindre betydning. Optimalt burde vi have foretaget flere interview for at få en bredere vifte af de studerendes oplevelser og dermed en større grad af datamætning (Kvale, \& Brinkmann, 2015). Da det i 2017 blev muligt at indsætte egne spørgsmål i den elektroniske kursusevaluering på AU, valgte vi at indsætte spørgsmål relateret til portfolioopgaverne. Vi bad også de studerende liste tre positive og tre negative ting ved portfolioopgaverne. Selv om disse udsagn ikke kan erstatte den mere nuancerede viden, der kan indsamles gennem kvalitative interviews, så giver det mulighed for at generere viden om, hvad de studerende oplever som godt og mindre godt ved portfolioopgaverne. Vi har i denne artikel anvendt en tematisering af de studerendes udsagn, hvilket har været relevant for at skabe overblik og finde tendenser. Tematiseringen siger dog ikke noget om, hvilken vægtning de studerende tillægger deres udsagn.

\section{Diskussion af forløb}

Det er en spændende og lærerig proces at udvikle og gennemføre portfolioopgaverne, og vi vil i de næste afsnit komme ind på nogle af de helt centrale emner, som har haft stor betydning. De centrale emner, der både diskuteres ud fra underviseres og studerendes synspunkt, er tekniske udfordringer, arbejdsbyrde samt erfaringer med opgavernes opbygning.

\section{Tekniske udfordringer}

De tekniske udfordringer har været omfattende. Redskabet, som bliver benyttet, er Bb's peer feedback-redskab, som ved afvikling af det første kursus ikke var taget i brug mange steder på AU. De tekniske udfordringer har dog vist sig ikke at have så meget at gøre med et nyt værktøj, selv om kompleksiteten har krævet, at underviserne har brugt en del tid på at lære det at kende. De største problemer har været deciderede programfejl, og da et peer feedback-værktøj laver komplicerede loops ved fordelingen af opgaver til evaluering, kan fejl, der resulterer i brud på disse loops, betyde omfattende manuelt arbejde og behov for teknisk indsigt for at genoprette administrationsprocedurerne. Det har derfor været umuligt at benytte et værktøj med programfejl uden støtte fra en e-læringskonsulent.

Der er stor forskel på, hvor fortrolige de studerende er med brug af Bb. På baggrund af erfaringer fra de første portfolioopgaver har underviserne valgt at få udarbejdet elektroniske vejledninger til de studerende med screenshot og beskrivelse af, hvordan opgaver uploades, og hvordan der teknisk gøres i forbindelse med peer feedback. Med disse elektroniske vejledninger opleves, at færre studerende kontakter underviserne med tekniske udfordringer. Det ses da også af de kategoriserede udsagn i den skriftlige evaluering, at meget få studerende oplever, at det tekniske er et problem. Vi antager derfor, at det ikke volder de studerende problemer at orientere sig $i$ et peer feedback-system, når der er klare introduktioner og vejledninger til opgaven.

\section{Arbejdsbyrde}

En ulempe forbundet med gennemførelse af portfolioopgaverne er, at der er en forholdsvis stor byrde forbundet med at vurdere opgaverne og give de studerende feedback, hvilket især opleves ved gennemførelsen i 2016, hvor studerende afleverede alle portfolioopgaver individuelt. Indivi- 
duelle portfolioopgaver giver god mening ved portfolioopgaver med peer feedback, men ved gennemførelsen i 2017 blev de to opgaver uden peer feedback ændret til gruppeopgaver med 46 studerende i hver gruppe. De studerende afleverer således én samlet gruppebesvarelse og bed $\varnothing$ mmes på baggrund af denne besvarelse. Dermed skal underviseren bed $\emptyset$ mme og give feedback på færre opgaver, hvilket frigiver tid til bl.a. at give en mere uddybende feedback på disse gruppeopgaver. Da portfolioopgaverne er indstillingsbetingelse til eksamen, kræves det, at den enkelte studerende kan vælge at aflevere sin egen opgave. Underviserne har derfor udarbejdet dokumentation, der beskriver håndteringen af dette.

Selv om to af portfolioopgaverne er ændret fra individuelle opgaver til gruppeopgaver, er der fortsat en betydelig arbejdsbyrde forbundet med at vurdere og give de studerende feedback på de fem portfolioopgaver, da underviserne også gennemgår den feedback, som de studerende giver medstuderende. I foråret 2017 har to ph.d.-studerende derfor hjulpet med at vurdere portfolioopgaverne. Den ene ph.d.-studerende var evaluator på portfolioopgaver 1 og 2, og den anden ph.d.-studerende var evaluator på portfolioopgaver 4 og 5. De ph.d.-studerendes bedømmelse og feedback til de studerende er sket med vejledning og sparring af underviseren. Selv om inddragelse af de ph.d.-studerende har været med til at lette arbejdet for underviseren, kræves det fortsat, at underviseren afsætter tid til vejledning og sparring med den ph.d.-studerende. Det er vores oplevelse, at involvering af ph.d.-studerende i bedømmelse og feedback har været en god og afgrænset undervisningsopgave for de ph.d.-studerende.

Det er også værd at overveje, hvad brugen af portfolioopgaverne og peer feedback betyder for de studerendes arbejdsbyrde. Både de studerendes udsagn og det faktum, at studerende vælger at gennemføre portfolioopgave 4 og 5 , selv om de har bestået de tre første, viser, at de studerende finder, at den læring, de opnår, er vigtig og en eventuel ekstra arbejdsbyrde værd. 5 ud af 10 studerende, der i første omgang havde misforstået deadline på en opgave, vælger endda at gennemføre den alligevel, som eksamensforberedelse. Der er flere af de negative udsagn fra kursusevalueringen, der går på planlægningen, og som viser, at det har betydning for de studerende, at portfolioopgaverne planlægges under hensyn til andre kursers større opgaver, for at de studerende samlede arbejdsbyrde i bestemte perioder ikke bliver for stor.

\section{Erfaringer med opgavens opbygning}

I forhold til temaet forløb har de studerende i den skriftlige evaluering foruden tekniske udfordringer og planlægning primært små konkrete forslag, der går på, hvad der kunne fungere bedre omkring opgavens opbygning. De fleste har nemt kunnet indarbejdes, og derfor har fokus i opbygning af opgaverne primært været på brugen af feedbackvejledninger og rubrics.

Ved flere af portfolioopgaverne har underviserne valgt at anvende kriteriebaserede feedbackvejledninger og rubrics. Netop brug af rubrics har vist sig at kunne bidrage til at skabe gennemsigtighed $\mathrm{i}$ bedømmelsen og derigennem styre feedback-processen (Panadero, 2013). Det er undervisernes klare oplevelse, at de studerende anvender de givne feedbackvejledninger og rubrics. I forbindelse med peer feedback har feedbackvejledningerne i nogle tilfælde været synlige allerede under opgaveskrivning, og i andre er de først gjort synlige i forbindelse med afgivelse af peer feedback i evalueringsperioden. De studerende har overordnet givet tilbagemeldinger på, at de oplever, at opgaven bliver mere overskuelig, når feedbackvejledning og rubric er synlige fra starten af portfolioopgaven. Det stemmer godt overens med, at feedbackvejledninger og rubrics kan være med til at give de studerende en større tryghed i løsning af opgaven samt $\emptyset$ ge de studeren- 
des selvregulering. Anvendelse af rubrics kan derfor samlet set medvirke til, at de studerende udarbejder en bedre opgave (Panadero, 2013).

\section{Diskussion af de pædagogiske principper}

Portfolioopgaverne er en gennemgående og omfangsrig aktivitet på kurset, som er valgt netop for at støtte op omkring de bærende pædagogiske principper, der vedrører constructive alignment, formativ feedback og peer feedback. Det er derfor også vigtigt, at de studerende som følge af denne aktivitet oplever en tilføjelse af merværdi, der hænger sammen med de pædagogiske principper. I det følgende vil de pædagogiske principper blive diskuteret op imod artiklens formål om at undersøge, hvordan portfolioopgaver kan bruges til at skabe sammenhæng i undervisningsforløb, sikre, at de studerende arbejder med det faglige stof imellem undervisningsgangene, og gør de studerende til medskabere af undervisningen ved brug af peer feedback.

\section{Sammenhængende undervisningsforløb}

For at underst $\varnothing$ tte et sammenhængende undervisningsforløb er der valgt et pædagogisk princip om constructive alignment, som i praksis understøttes af de skriftlige portfolioopgaver, der skal forberede de studerende på eksamen.

De studerende oplever denne sammenhæng, og i den skriftlige evaluering går udtalelser kategoriseret under Constructive alignment på, hvordan de umiddelbart kan relatere portfolioopgaverne til både kursets læringsmål og eksamen.

Både de studerendes skriftlige kommentarer i evalueringen og udtalelsen i interviewet 'og vi fik faktisk lov at prøve det to gange, så det var supergodt at bygge det op, og til eksamen der vidste jeg, hvad det er, det handler om' indikerer, at de studerende i portfolioopgaverne oplever, at de formative aspekter med gentagelser fører til brug af dybdelæringsstrategier gennem refleksion og får kurset til at fremstå sammenhængende både i sine enkeltdele og i forhold til læringsmål og eksamen.

\section{Læring mellem undervisningsgangene}

Det pædagogiske princip om formativ feedback skal underst $\varnothing$ tte, at de studerende mellem undervisningsgangene arbejder med det faglige stof og får feedback på dette arbejde.

De gentagne portfolioopgaver er tænkt til at understøtte både repetition og det formative aspekt, da de altid følger op på undervisningen og giver de studerende feedback i forhold til deres arbejde med det faglige stof mellem undervisningsgangene. I den skriftlige evaluering viser de studerendes udtalelser kategoriseret under formativ feedback, at de synes, at portfolioopgaverne samler op, er relevante og hænger godt sammen med praksis og det netop gennemgåede stof. Og da underviserne in class overordnet gennemgår portfolioopgaver og besvarelser, skabes yderligere sammenhæng, og de studerende kan drage fordel af mulighederne ved formative feedback (Biggs \& Tang, 2011) videre i kurset samt opnå den feed forward (Hattie, 2007), som var tilsigtet.

Samtidig får underviserne gennem portfolioopgaverne en indsigt i de studerendes niveau, som kan bruges til at korrigere den planlagte undervisning. Underviserne har både oplevet at have haft en fornemmelse af et lavt niveau hos de studerende på et område, som blev afkræftet gennem de studerendes portfolioopgavesvar, og opdaget manglende begrebsforståelse, som har 
betydet, at de med udgangspunkt i Just in Time Teaching (Novak et al., 1999) har justeret undervisningen, så det aktuelle behov blev imødekommet.

\section{Peer feedback og de studerende som medskabere af undervisning}

Det pædagogiske princip om peer feedback er valgt både for at underst $\varnothing t t e$ indre og ydre feedbackprocesser og for at inddrage de studerende som medskabere af undervisningen.

I den skriftlige evaluering omhandler mange af de studerendes kategoriserede udsagn, hvordan portfolioopgaverne underst $\varnothing t t e r$ refleksion og brug af dybdelæringsstrategier, da de studerende er nødt til at have et dybt kendskab til stoffet for at kunne løse cases og give feedback. Dette understøttes i interviewet: 'jeg synes virkelig, jeg har fået sat på plads, hvad handler det her egentlig om?'.

Tre af portfolioopgaverne indeholder peer feedback, og den skriftlige evaluering viser, at de, når de skal give feedback på en anden studerendes opgave, i høj grad tilskyndes til at reflektere og derved gøre brug af dybdelæringsstrategier. En grund til dette er den måde, hvorpå man er nødt til at både at have overblik og kende stoffet i dybden, når man skal give feedback til andre. De studerende oplever et ansvar i forhold til at give en ordentlig feedback, hvilket kommer til udtryk i interviewet: 'Og man skylder jo også at give en god feedback til den, der har lavet et stykke arbejde.' Der sker derfor en adfærdsændring (Nicol \& Macfarlane-Dick, 2006) i de studerendes læringsstrategier, og de studerende bliver medansvarlige også for andre studerendes læring og medskabere af undervisningen. Her kan det også have en betydning, at de studerende bedømmes på den feedback, de giver. Dette er der dog ingen studerende, der nævner.

Flere studerende udtaler i den skriftlige evaluering, at de får noget ud af at læse andre studerendes opgaver, se, hvordan andre formulerer sig og besvarer de samme spørgsmål, som de selv har besvaret. De studerende giver i den skriftlige evaluering også udtryk for, at de udnytter det, de læser, og sammenligner med deres egne besvarelser, eller som det udtrykkes i interviewet: ' $h v o r$ jeg tænkte, at det skulle jeg måske også have brugt'. Herved oplever de studerende en selvregulering (Nicol \& Macfarlane-Dick, 2006), og de får indre feedback (Nicol et al., 2014), som de kan bruge fremadrettet. Dette udtrykkes også i interviewet: 'så der fik jeg jo nogle gode tips til, hvordan jeg kan lave min opgave en anden gang'.

Også den ydre feedback bør kunne bruges af de studerende, men på dette område er evalueringen ikke helt entydig. Generelt er de studerende meget tilfredse. $60 \%$ er enige i, at de har gode muligheder for at få tilbagemelding på deres faglige præstationer, og yderligere $25 \%$ er delvist enige. Også i interviewet giver den studerende udtryk for at være rigtig glad for den feedback, som hun får: 'og vedkommende, der rettede min opgave, var heller ikke en, som bare skrev: 'Hvor er det flot' ... men der var også noget kød på, hvor vedkommende skrev, at jeg kunne måske også have gjort det eller det ... på en venlig måde, men alligevel hvor jeg godt kunne se, at det har du fuldstændig ret i'. Derfor var der også en forventning om, at ydre feedback fra medstuderende ville være en positiv kategori i de studerendes udsagn om portfolioopgaverne. Imidlertid er der ingen af de positive udsagn fra evalueringen, der beskriver den ydre feedback fra medstuderende, mens flere af de negative går på manglende feedback, på trods af at det bliver angivet af underviseren, hvis en feedback er mangelfuld.

Der kan være flere grunde til dette gab imellem en stor generel tilfredshed med feedback og manglende positive udsagn om det. En mulig forklaring kan være, at de studerende oplever så mange positive aspekter af portfolioopgaverne, at feedback fra medstuderende ikke hører 
blandt de tre vigtigste grunde, og samtidig oplever de så få negative aspekter, at det bliver en af de vigtigste, når de synes, feedback er mangelfuld. Dette kan ikke udledes af evalueringen, da de studerende ikke vægter deres udsagn. En anden grund kan være, at feedback hos studerende stadig er tæt forbundet med opfattelsen af, at det skal gives af en underviser, og at den metarefleksion omkring portfolioopgaverne, som sker hos den interviewede studerende, måske har rykket ved denne opfattelse. Endelig kan der være tale om, at de studerende rent faktisk mangler feedback, da dette i de første peer feedback-opgaver kun skulle gives ved forkerte eller delvist dækkende besvarelser, men ikke når besvarelserne var fuldt dækkende. Dette er senere ændret, men har muligvis ikke nået at slå igennem i evalueringen. Der kan ikke konkluderes noget endegyldig her omkring forklaringen, men det vil være interessant at undersøge nærmere.

Det er vores overordnede vurdering, at portfolioopgaverne og de pædagogiske principper bag disse opgaver generelt betyder, at de studerende opnår en hensigtsmæssig læring og er tilfredse med den feedback og tilbagemelding på deres faglige arbejde, som de modtager. Vi mener dog, at det er værd også fremadrettet at arbejde med de studerendes forståelse af og inddragelse i feedbackprocesserne og deres kompetencer $\mathrm{i}$ forhold til at give, men især modtage feedback for at kunne styrke deres anvendelse af ydre feedback fra medstuderende og $\varnothing$ ge deres læring gennem fokus på, hvordan denne feedback bruges i den videre læring (Heen \& Stone, 2015).

\section{Konklusion}

Brug af portfolioopgaver som indstillingsbetingelse til eksamen på kurset Tværfaglig og Tværsektoriel Rehabilitering har skabt en sammenhæng og constructive alignment i kursusforløbet. Løsning af portfolioopgaverne har sikret, at de studerende arbejder med det faglige stof mellem undervisningsgangene, og vi vurderer, at det sammen med brug af peer feedback har bidraget til at fremme de studerendes brug af dybdelæringsstrategier og øget refleksionen.

Portfolioopgavernes placering i tæt emnemæssig relation til det stof, der præsenteres til forelæsninger og holdtimer, øger under selve kurset de studerendes forståelse af stofområdet og de faglige begreber samt forståelse for relationer mellem begreberne og den praktiske anvendelse af stoffet. Den formative feedback fra både undervisere og medstuderende kan fungere som feed forward i forhold til de studerendes læring i det resterende kursus.

Det kan tyde på, at undervisningsformen på dette kursus har betydning for en positiv kursusevaluering af de studerendes oplevelse af feedback. De studerende er særligt glade for den indre feedback i forbindelse med at læse og evaluere medstuderendes opgaver, mens tiltag, der kan $\emptyset$ ge en værdsættelse af medstuderendes eksterne feedback, kan overvejes i fremtiden.

Det er vigtigt, at de komplicerede processer ved peer feedback understøttes af et stabilt og velfungerende digitalt peer feedback-værktøj. Derudover kan det være hensigtsmæssigt, at der tilknyttes ressourcer, f.eks. i form af ph.d-studerende, der som undervisningsassistenter kan involveres i feedback og bedømmelse af portfolioopgaverne under vejledning og sparring med underviseren. Kriteriebaserede feedbackvejledninger og rubrics højner kvaliteten og de studerendes tryghed både i opgaveskrivning, i evalueringsprocessen og ved modtagelse af peer feedback. 
Lisa Gregersen Østergaard er uddannet som ergoterapeut, cand.scient.san, ph.d. Hun er ansat som klinisk specialist i Fysioterapi- og Ergoterapiafdelingen, Aarhus Universitetshospital og som adjunkt ved Institut for Folkesundhed, Aarhus Universitet.

Thomas Maribo er uddannet som fysioterapeut, cand.scient.san., ph.d. Han er ansat som lektor på Sektion for Klinisk Socialmedicin og Rehabilitering, Institut for Folkesundhed, Aarhus Universitet, og som seniorforsker og programleder i Rehabilitering og sygefravær, DEFACTUM, Region Midtjylland.

Janne Saltoft Hansen er cand.mag. i informationsvidenskab. Hun er ansat som elæringskonsulent på Center for Sundhedsvidenskabelige Uddannelser (CESU), Health, Aarhus Universitet, og fungerer som projektleder for Blackboard på Health

\section{Referencer}

Aarhus Universitet. (2017). Studiemiljø 2017: Undersøgelse af studiemiljøet ved Aarhus Universitet. Aarhus: Aarhus Universitet.

Braun, V., \& Clarke, V. (2006). Using thematic analysis in psychology. Qualitative research in psychology, 3(2), 77-101.

Biggs, J. \& Tang C. (2011). Teaching for quality learning at university: What the student does. Maidenhead: McGraw-Hill Education (UK).

Hattie, J., \& Timperley, H. (2007). The power of feedback. Review of educational research, 77(1), 81-112.

Heen, S \& Stone, D. (2015) Thanks for the Feedback - The Science and Art of Receiving Feedback Well. Portfolio Penguin (UK)

Herrmann, K. J., \& Bager-Elsborg, A. (2014). Effektiv holdundervisning: En håndbog for nye undervisere på universitetsniveau. Frederiksberg: Samfundslitteratur

Kvale, S. \& Brinkmann, S. (2015). Interview: det kvalitative forskningsinterview som håndværk. København. Hans Reitzel

Nicol, D. J., \& Macfarlane-Dick, D. (2006). Formative assessment and self-regulated learning: A model and seven principles of good feedback practice. Studies in higher education, 31(2), 199-218.

Nicol, D. (2010) From monologue to dialogue: Improving Written Feedback Processes in Mass Higher Educations. Assessment \& Evaluation in Higher Educations, 35 (5), 501-517.

Nicol, D., Thomson, A., \& Breslin, C. (2014). Rethinking feedback practices in higher education: a peer review perspective. Assessment \& Evaluation in Higher Education, 39(1), 102-122.

Novak, G. M., Patterson, E. T., Gavrin, A. D., \& Christian, W. (1999). Just-in-Time Teaching: Blending Active Learning with Web Technology. Upper Saddle River, NJ: Prentice Hall.

Panadero, E. \& Jonsson A. (2013). The use of scoring rubrics for formative assessment purposes revisited: A review. Educational Research Review. 9, 129-144.

Sadler D. R. (1989) Formative assessment and the design of instructional systems. Instructional Science. 18, 119-144. 
Smith, K., \& Tillema, H. (2003). Clarifying different types of portfolio use. Assessment \& Evaluation in Higher Education, 28(6), 625-648.

Wood, D. F. (2010). Formative assessment. Understanding medical education: Evidence, theory and practice, 9, 317-328. 